\title{
きつい曲がり管内入口流れの壁面せん断応力*
}

\author{
鈴木 淳 一*1, 大石尚 史*2, 谷下一夫*3
}

\section{Wall Shear Stress Profile of the Entrance Flow in a Strongly Curved Tube}

\author{
Jyunichi SUZUKI, Naobumi OHISHI and Kuzuo TANISHITA
}

\begin{abstract}
The distribution of the wall shear stress in the developing flow of a strongly curved tube with the curvature ratio, defined as the ratio of the tube radius to the radius of curvature, of $1 / 2,1 / 3$, and 1 / 7 , was measured by means of the electrochemical limited current method for the Dean number range of 139 to 372 . The working fluid is the aqueous solution of potassium ferro- and ferricyanide. In the upstream region, the wall shear stress at the inner wall shows the maximum, and this maximum shear stress shifts towards the outer wall for both parabolic and uniform entrance velocity profiles. It should be noted that the maximum shear stress achieved in the middle portion of the curved tube increases with the increase in the curvature ratio. This nonuniformity of wall shear stress profile is associated with the localization of atherogenesis found in the curved arterial vessels.
\end{abstract}

Key Words: Flow Measurements, Curved Tube, Blood Flow, Secondary Flow, Biological Engineering

\section{1. 緒}

動脈硬化などの血管病変が主に太い動脈の曲がり部 の内側や分岐部に局所的に生ずるという知見が医学者 によって得られ, 病変の局在性と血管内の流動性状と の関連が注目されている(1). 血管内流机の流体力学的 パラメータの中でも，血管病変に最も影響を与える因 子は壁面せん断応力であると考えられ，動脈内の壁面 せん断応力の様子を明らかにする必要がある。

動脈の中でも病理学的な所見により曲がりの内側に 病変が頻度高く認められる大動脈弓(2) や内けい動脈 ${ }^{(3)}$ は，曲率の大きい曲がり管である。ところがこれまで の多くの曲がり管内流れの研究は, 曲率の小さい場合 がほとんどであった，比較的曲率の大きな曲がり管内 の流れについては, Olson' ${ }^{(4)}$, Bovendeerd ら(5)によっ て曲率比 $\delta=1 / 6$ までについて速度分布の測定が行わ 机ている。坂田による病理学的な研究(3)によると，内 けい動脈の曲率比は $1 / 2$ 以上という極めて大きな值を とるという。これまで著者らにより曲率比 $\delta=1 / 2$ ま

* 原稿受付 平成 3 年 6 月 3 日.

*1 東京ガス(侏)（日105 東京都港区海岸 1-5-20).

*2 (株)雨通( 6530 大阪市北区堂岛 2-4-5).

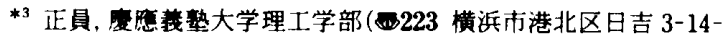
1).

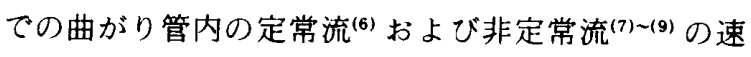
度分布がレーザドップラー流速計によって測定され， 大きな曲率による影響が次第に明らかになってきた。 しかしながら，LDVによって得られた速度分布から 壁面せん断応力を求めると大きな誤差が生ずる。妥当 な信頼性を持つせん断応力の測定法として電気化学的 方法(10) が知られており，曲がり管内流れ(11) や腹部大 動脈モデル内(12) の壁面せん断応力の結果が報告され ている.

本研究では, 血管病変の局在性との関連を明らかに することを目的として，曲率の大きい曲がり管内壁の せん断応力を電気化学的方法で測定し, 壁面せん断応 力の分布の特徵に関する知見を得た。

\section{記 号 表}

\section{$a:$ 管内半径}

$A:$ 電極面積

$C:$ フェリシアンイオン濃度

$d_{e}:$ 電極の直径

$D_{f}:$ フェリシアンイオンの拡散係数

$F:$ ファラデー常数

$I_{0}:$ 直管内電極の限界電流値

$I_{L}$ : 限界電流值 
$R:$ 曲率半径

$S_{w}$ : 壁面せん断速度

$S_{0}$ :ポァソィユ流れにおける壁面せん断速度

$W:$ 管軸方向平均速度

$Z:$ 管軸方向無次元長さ $=R \varphi /(a R)^{1 / 2}$

$\delta:$ 曲率比 $=a / R$

$x:$ ディーン数 $=\delta^{1 / 2}(2 a W / 2)$

$\nu$ : 流体の動粘性係数

$\theta:$ 管断面内の周方向の角度

$\tau$ ：壁面せん断応力

$\tau_{0}$ :ポァゾィユ流れにおける壁面せん断応力

$\varphi:$ 曲がり部入口からの角度

\section{2. 実験装置および方法}

曲がり流路としては, 半円断面の漊が彫られている 2 枚のアクリル板を合せる方式により曲率比 $\delta=1 / 2$ (管内半径 $a=15 \mathrm{~mm}$ ), 1/3, 1/7 $(a=10 \mathrm{~mm}$ )の 3 種 類が製作された。曲がり流路の座標系を図 1 に示す。 $\delta=1 / 2$ の流路では曲がりの入口から $\varphi=0,30,60$, $90,120,150,180^{\circ}$ の断面に純ニッケル線 $\left(d_{e}=0.5\right.$ $\mathrm{mm}$ )を断面周方向 11 筒所に埋め込み, 限界電流の測 定のための陰極とした。 $\delta=1 / 3,1 / 7$ の流路では, 曲が りの入ロから $15,30,45,68,90,113,135,158^{\circ}$ の断 面に同様にニッケル線を埋め込んだ。

電気化学的方法とは, 酸化還元体を含む電解質溶液 を流路に流したとき，流路に設置したニッケル電極 (陰極)と，下流側に設置した陽極との間に壁面でのせ ん断応力に依存して限界電流が生ずることを利用する 方法である(10). 使用した酸化還元系水溶液はフェリシ アン化カリウム $\mathrm{K}_{3} \mathrm{Fe}(\mathrm{CN})_{6} 0.01 \mathrm{M}$ とフェロシアン 化力リウム: $\mathrm{K}_{4} \mathrm{Fe}(\mathrm{CN})_{6} 0.01 \mathrm{M}$ の混合液に補助電解 質として水酸化ナトリウム $1 \mathrm{M}$ 在加えたものである. そのとき，両極間に一定電圧を加えると次のような反 応が生ずる。

陰極: $\mathrm{Fe}(\mathrm{CN})_{6}^{3-}+\mathrm{e}^{-} \rightarrow \mathrm{Fe}(\mathrm{CN})_{6}^{4-}$

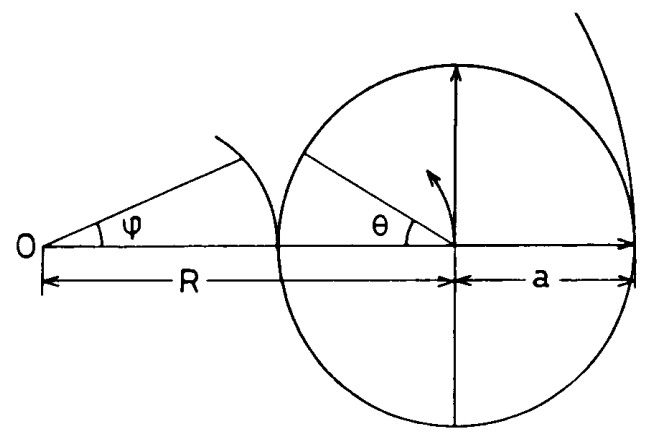

図 1 曲がり管内の座標系
陽極 $: \mathrm{Fe}(\mathrm{CN})_{6}^{4-} \rightarrow \mathrm{Fe}(\mathrm{CN})_{6}^{3-}+\mathrm{e}^{-}$

陰極表面でのフィリシアンイオンの拡散が律速となる ときの電流值 (限界電流) と壁面せん断速度との関係は 次式によって与えられる。

$$
S_{w}=\frac{1.545 d_{e} I_{L}^{3}}{D_{f}^{2}(A F C)^{3}}
$$

本研究では，曲がり管上流側の直管内で発達した流れ (ポァゾィユ流れ)での壁面せん断速度 $S_{0}$ で無次元化 した值(せん断応力の比に等しい)によって壁面せん断 応力の分布を整理した。

実験に使用した流路を図 2 に示す。一定高さのリザ 一バから静水圧下で曲がり流路に一様流およびポァソ イユ流れが流入するようにした，大動脈や内けい動脈 における血流を模擬するため， $x=139 \sim 372$ のディー

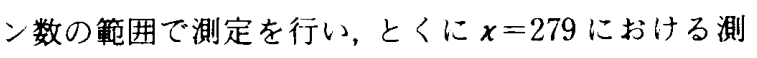
定結果について検討を行った.

\section{3. 結果およひ考察}

まず測定系の信頼性を確認するため, 直管部の断面 に設置した電極(11簓所)で测定された限界電流の值 から求めたせん断速度と, 理論値(ポアゾィユ流れ)と の比較を行った結果を図 3 に示す。実験値は理論值よ りもやや低い值 $(10 \%)$ を示している。せん断速度は式 (3)加わかるように限界電流值の三乗に比例し, 電 極の直径の五乗に逆比例しているため, 電極の大きさ や限界電流值の測定精度による影響が大きい. 本研究 では、ニッケル電極をアクリル板内に埋め込んだ状態 で、ボールエンドミルで半円状の溝を㰹ったため、と くに $\theta=90^{\circ}$ 付近の電極表面の径が素線の径から変化 する可能性がある。そこで，壁表面に露出した部分の

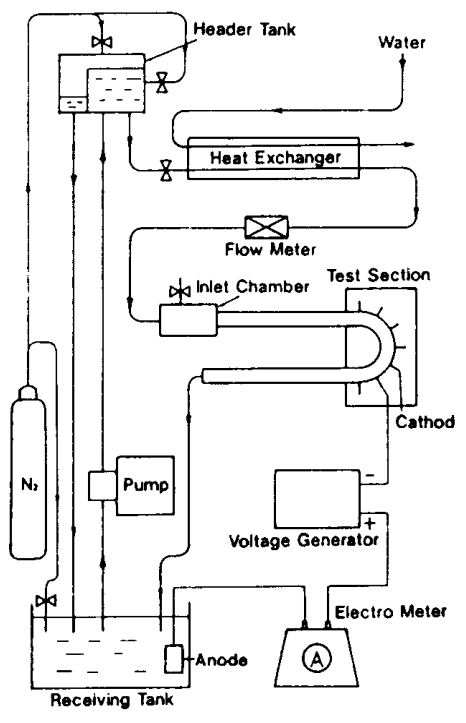

図 2 実験回路 
直径を読取り影微鏡により確認した。埋め込んだ状侁 での電極有効面稓を決定する方法として電位差纬引ポ ーラログラフ法(13) が知られているが, 本研究では静 止した状態での限界電流值を測定して電極の有効断面 積の補正に関して検討を行った。ささらにファリシアン イオンの滥度や拡散係数が電極における反応の進行に より変化するので，曲がり流路部での壁面せん断応力 の測定值に対しては，その絶対値よりも直管部で測定 した値との比で評価を試みた。

$3 \cdot 1$ 放物形速度分布で流入する堨合 図 4 は放 物形速度分布で流入した場合の $\delta=1 / 3$ の流路におい て入口からの角度 $\varphi=90^{\circ}$ の断面における壁面せん断 応力の測定結果であり, ディーン数 $=139 \sim 372$ の範囲 では，類似した傾向を示している，そこで本研究では， 曲率比が入口からのせん断応力の推移に与える影響を 明らかにするため, とくに $x=279$ の場合に限定して 検討を進めることとした。

図 5 (a) は $\delta=1 / 2$ のとの壁面せん断応力の曲が り部入口からの変化を示す。まず入口部では，せん断 応力は内壁側が高くなっている.LDVによる定常入口

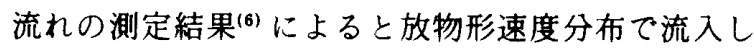
た場合、入口部で軸方向速度分布が下流側の曲がり部 の影響を受け，内壁側に寄り内壁側に向かう二次流れ が表れている．そのため壁面せん断応力の最大值が内 壁側に生じている.しかし，曲がり部に流入し，下流に 向かうにつれて壁面せん断応力の最大値が増加すると 同時に内壁側から次第に外壁側に移動する．測定され た二次流れの速度分布 ${ }^{(6)}$ によると， $\varphi=75^{\circ}$ の断面は 内壁側の壁付近の二次流れが大きく加速される部分で ある.図 5 (a)の $\varphi=60^{\circ}$ では最大值が急激に増加し ている部分とよく対応している，曲がり部出口である $\varphi=180^{\circ}$ ではせん断応力の最大值が外壁側付近に近づ

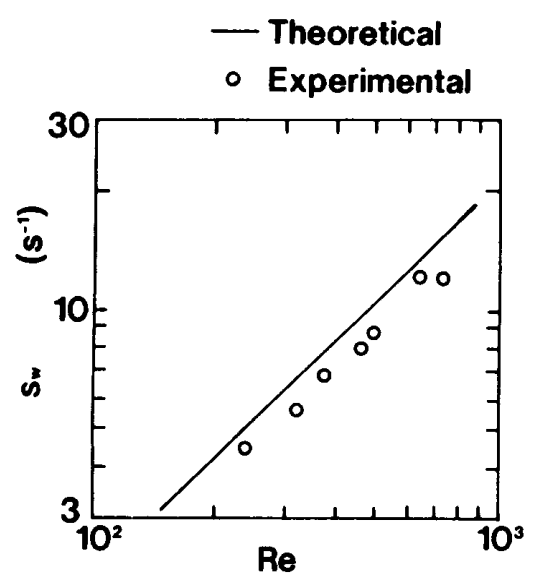

図 3 直円管内で湘定された壁面せん断速度
いている。このような壁面せん断応力の推移は，断面 内に生じた二次流れの発達に起因している(6). 放物形 入口速度分布の中心朝の最大速度による大きな遠心力 のため，外壁側に向かう二次流れが中心部に発生し， その結果壁面に治って内壁に向かう強い圧力こう配が 発生するため, 二次流れが著しく加速され，壁面せん 断応力の增加の原因となっている。ところが $\varphi=135^{\circ}$ の位置で付加渦が表れ，二次流れの速度が急激に減少 し，壁面せん断応力も低下している。

図 5 (b) は曲率比 $\delta=1 / 3$ の場合の結果である.入 口で内壁側に最大値が表れているが， $\delta=1 / 2$ の場合 と同様次第に外壁側に移行していく，下流に進むとと もに壁面せん断応力が著しく増加し，無次元壁面せん 断応力の最大值が $\varphi=68^{\circ}, \theta=90^{\circ}$ の位置で 7.0 に達 する. 軸方向速度分布が次第に外壁側に寄るため, 外 壁側でその影響が影著となり，次第に壁面せん断応力

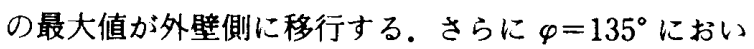
て，2箇所に極大値が表れる分布になっている。興味 深い点は,この断面において極小值を示す位置で付加 渦が発生して, 内壁に向かう二次流れの速度が低下し ていることである。

図 5 (c) に曲率比 $\delta=1 / 7$ の場合のせん断応力の変 化を示す．曲率が隇少すると $\delta=1 / 2,1 / 3$ の場合に見 られた最大せん断応力が著しく増加する特徴的な分布 が消滅する.入口からの角度 $\varphi=30^{\circ}$ の断面の $\theta=100^{\circ}$ で最大せん断応力が表れるが，最大值がいったん内壁 に寄ってから次第に外壁側に移行していく．前述のよ うに壁面せん断応力の変化は, 断面内に誘起された二 次流れの様子に対応している.LDVによる速度分布の

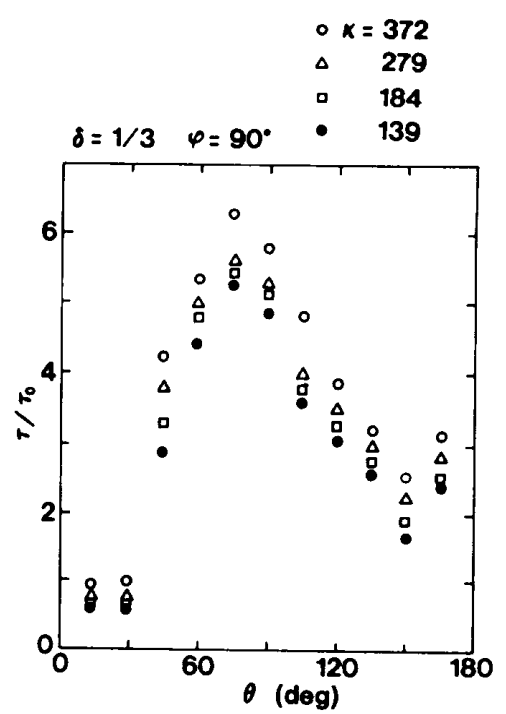

図 $4 \delta=1 / 3, \varphi=90^{\circ}$ の断面で測定された無次元壁面せん 断応力 
測定結果によると, 曲がり管内入口領域で二次流れは 著しく加速され，その大きさには影著な曲率依存性が 見られる。したがって壁面せん断応力の推移にも曲率 比の影䇾が表れてくる．とくに放物形速度分布で流入 する場合の特幑は，入口付近の断面中心部における外 壁側に向かう二次流れの加速である。この二次流れが 曲率比に依存しているため, 結果的に大きな曲率を持 つ曲がり管内流れでは，入口領域の壁付近で内壁に向 かう二次流れの流速が増大し, 壁面せん断応力の増加 をもたらす。

$3 \cdot 2$ 一滕流入速度分布の堨合 次に一様流入速 度分布の場合の結果を図 6 (a) に示す. $\varphi=15^{\circ}$ におい ては，境界層がまた薄く境界層外側の非粘性領域のポ テンシャル渦のために最大值が内側に寄る分布をして いる.しかし，次第に境界首が発達し，同時に二次流れ が誘起され, $\varphi=45^{\circ}$ の断面から $\theta=60^{\circ}$ に最大值が表 れる.しかし放物形入口速度分布の場合上り低く， $\varphi=$ $45^{\circ}$ における無次元せん断応力の最大值は, 放物形の 場合の $63 \%$ である.さらに下流に向かうにつれてせん 断応力の最大值が増加し， $\varphi=113^{\circ}$ で最大に達した後 減少し，極小值が表れる分布となる。図 $7 に \varphi=45^{\circ}$ に
おける二次流れの計測結果を示すが, 放物形速度分布 で流入する場合〔図 7(a)〕は, $\theta=75 \sim 90^{\circ}$ の壁付近 に大きな速度が表れるが, 一様流入速度分布の場合

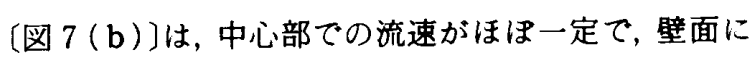
沿って内壁側に向かう流速も，放物形速度分布で流入 する場合ほど大きくならない。そのため，一様速度で 流入する場合は, 壁面せん断応力も放物形速度分布で 流入する場合ほど増加しない。

曲率比が $1 / 7$ になると図6 (b)に示されるようにせ ん断応力の著しい増加が見られなくなる．さらに本研 究で得られた值はChoi ら(11)による測定值に近いこ とがわかる。

$3 \cdot 3$ 壁面せん断応力の軸方向の变化 図 5,6 から放物形，一様流入速度分布の場合も入口からのせ ん断応力の発達が曲率比によって影響を受けているこ とがわかる、この傾向は, せん断応力が著しく増加し ている周方向位置 $\theta=75^{\circ}$ のせん断応力の軸方向距離 に対してプロットした結果 [図 8(a)，(b)]に明りょ うに表れている，図8（a）は放物形流入の場合で, 軸 方向距離は曲がり管内入口領域の代表長さ $(a R)^{1 / 2} て ゙$ 無次元化してある.図 8 (a) では, 曲率比 $\delta=1 / 3$ の時

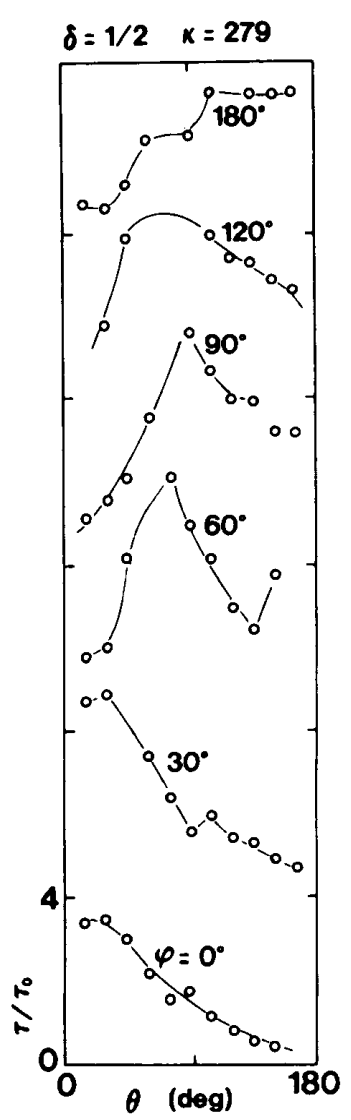

(a) $\delta=1 / 2$

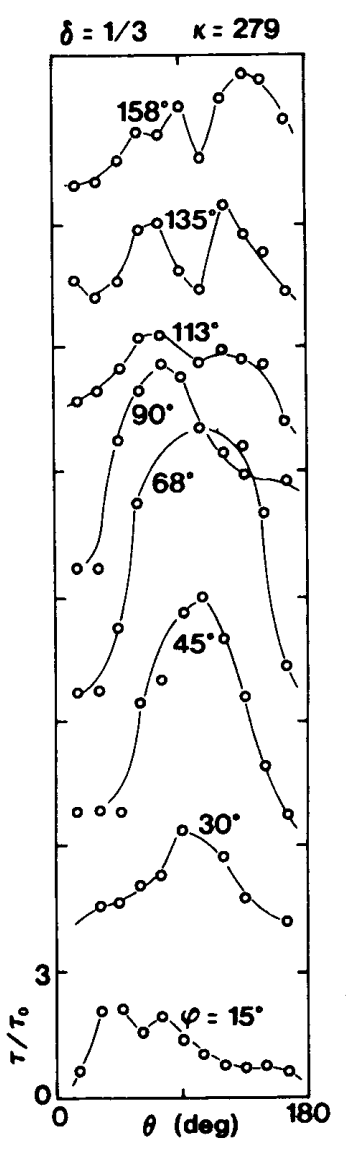

(b) $\delta=1 / 3$

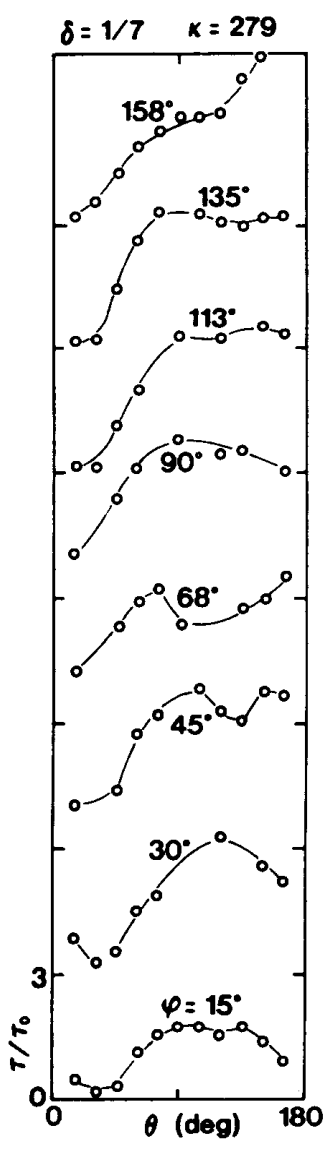

(c) $\delta=1 / 7$

図 5 放物形速度分布で流入する場合の無次元壁面せん断统力の分布 

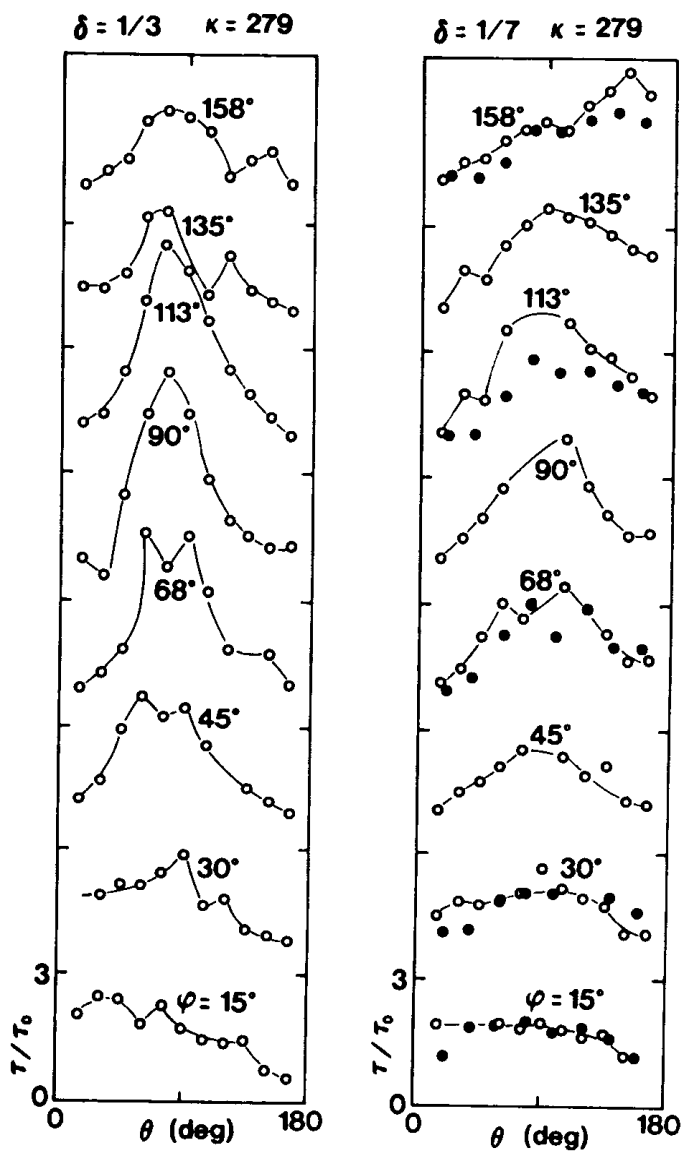

(a) $\delta=1 / 3, \quad x=279$

(b) $\delta=1 / 7, x=279, \quad$ : Choi s :上る測定結果, $\bigcirc$ : 本研究

図 6 一様速度分布で流入する場合の無次元壁面せん 断応力の分布 $(\delta=1 / 3, x=279)$

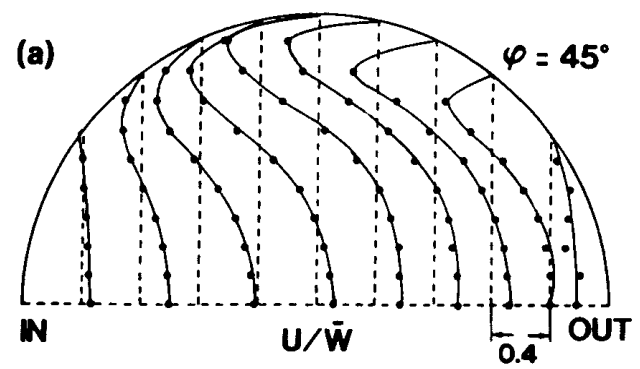

（a）放物形速度分布で流入する場合， $\varphi=45^{\circ}$ にお $\forall$ る無次元二次流れ速度 $(U / \bar{W}, U$ : 対称面 の方向心次流れ速度， $\bar{W}$ : 断面平均流速) $(\delta=1 / 3, x=279)$

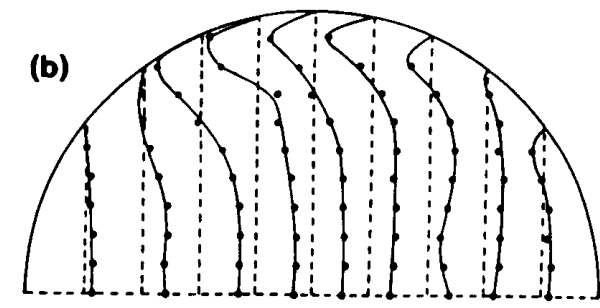

(b) 一様速度で流入する場 合の無次元-二次流れ速度

図 7
無次元距離 $=2.0$ の位置で最大となり，その值も $\delta=$ $1 / 7$ の最大値の 1.8 倍となっている。しかし下流に向 かうにつれ，発達した流れの值に近づくと，曲率比の 影響は消失する傾向を示す. 図 8 (b)に, 一様速度分 布で流入する場合の結果を示す. $\delta=1 / 3$ の場合の最大 值は, 放物形速度で流入する場合の最大値よりも $13 \%$ 低く，その最大値の表れる無次元距離は，放物形流入 の場合よりも長い，すなわち放物形入口速度分布の場 合は，曲がり管入口において中心軸付近の大きな遠心 力により，二次流れが入口付近で加速されるが，一様 入り口速度分布の場合は，境界首が徐々に厚くなって， 二次流れが形成されるため,やや下流側で最大值に達 する.

血流と直接接触する動脈壁の内皮細胞は, 流れの壁 面せん断応力によって，変形，配向したり，物質を分 泌する事実が明らかにされてきた(14).したがって流れ のせん断応力により影響を受ける内皮細胞のふるまい

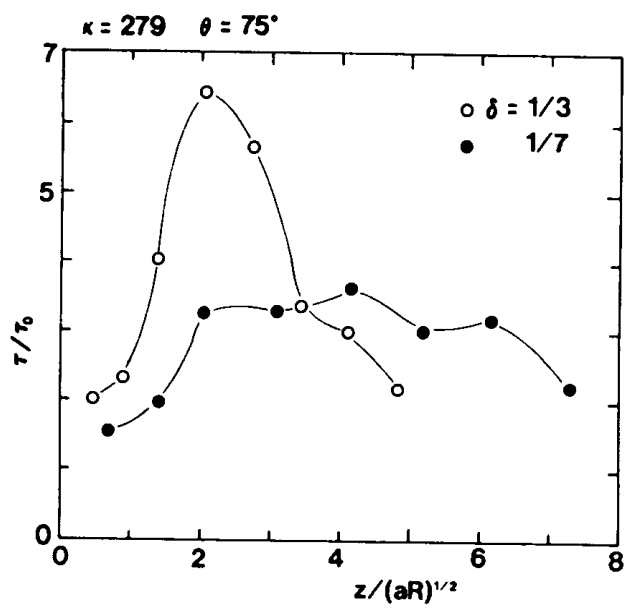

（a）放物形速度分乕で流入する場合

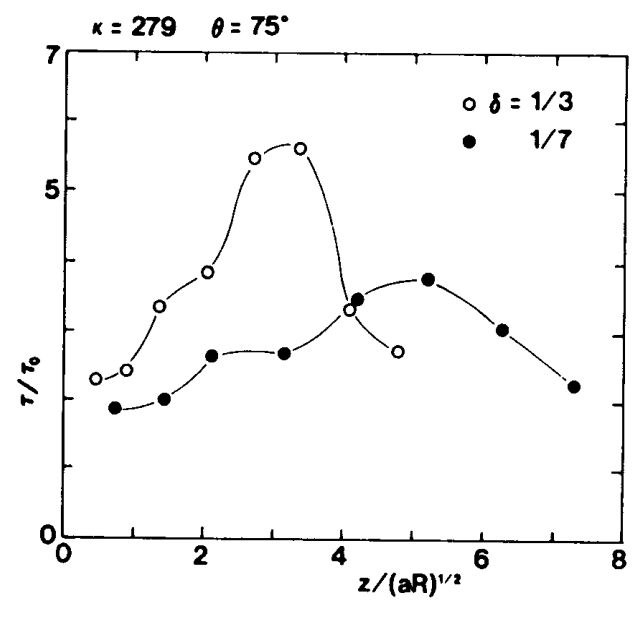

(b) 一棣速度分布で流入する場合

図 $8 \theta=75^{\circ}$ における無次元壁面せん断応力の軸方向 変化 
が, 血管病変の発生と関連が深いことから, 内皮細胞 のバイオメカニクスに関する研究が行われてい る(15).これまで血管病変に対する血流の影響について は, いくつかの相反する仮説が提唱されている(1).こ れらの見解を整理する一つの糸口として本研究で得ら れたようなモデル動脈における壁面せん断応力の分布 と動脈湾曲部での内皮細胞の機能との関連が明らかに なれば, 湾曲部を持つ動脈病変に対する血流の役割が 明確になるであろう。

\section{4. 結}

曲がり管内定常流入口領域において，二次流れは著 しく加速され，壁面せん断応力が増大する，その大き さは曲率比が大きいほど大きいという著しい曲率比依 存性を示す，曲率を持つ動脈内入口領域でのせん断応 力の推移は血管病変の局在性と関連している. 電気化 学的方法による壁面せん断応力の測定に関して, 当時 卒業研究の学部生であった勝岡修二氏，佐々木重直氏， 片山一郎氏，博士課程の大学院生であった成瀬岳史氏 のご助力を得た。

\section{文献}

(1) Nerem, R. M. and Cornhill, J. F., J. Biomech. Eng., 102 (1980), 181.

(2) Chang, L. T. and Tarbell, J. M., J. Fluid Mech., 161 (1985), 175

（3）坂田・町並 - 城下 ・ 大根田, 眽管学, 25-11 (1985) 1255.

(4) Olson, D. E. and Snyder, B., J. Fluid Mech., 150(1985), 139.

( 5 ) Bovendeerd, P. H. M., Steenhoven, A. A. van, Vosse, F. N. van de, and Vossers, G., J. Fluid Mech., 177(1987), 233.

（6）谷下 - 鈴木 - 大石・成瀬，機論, 57-535, B(1991), 898.

(7) 成頼・仁科・久下沼・谷下，機論, 56-529, B(1990), 2562.

（8）成瀨・ 代科・久下沼・谷下，機論, 56-532, B(1990)， 3625 .

（9）成瀨 - 仁科 - 石原 - 谷下, 機論, 57-541, B(1991) 3018.

(10) Mizushina, T., Adv. Heat Transf., 87(1971), 87.

(11) Choi, U. S., Talbot, L. and Cornet, I., J. Fluid Mech., 93 (1979), 465.

(12) Lutz, R. J., Cannon, J. N., Bischoff, K. B., Dedrick, R. L., Stiles, R. K. and Fry, D. L., Circulat. Res, 41 (1977), 391.

(13) Lutz, R. J., Menawat, A. and Peterson, J. I., AIChE J., 28(1982), 1027.

(14) Levesque, M. J. and Nerem, R. M., J. Biomech. Eng., 107 (1985), 341.

(15) Chien, S., Vascular Endothelium in Health and Disease, (1988), 59, Plenum Press. 